\title{
Pregnancy and interferon $\tau$ regulate DDX58 and PLSCR1 in the ovine uterus during the peri-implantation period
}

\author{
Gwonhwa Song ${ }^{1}$, Jo-Ann G W Fleming ${ }^{2}$, Jinyoung Kim ${ }^{1,2}$, Thomas E Spencer ${ }^{2}$ \\ and Fuller W Bazer ${ }^{1,2}$ \\ ${ }^{1}$ WCU Biomodulation Major, Department of Agricultural Biotechnology, Seoul National University, 599 Gwanak-ro, \\ Gwanak-gu, Seoul 151-921, Korea and ${ }^{2}$ Department of Animal Science, Center for Animal Biotechnology and \\ Genomics, Texas A\&M University, 442 Kleberg Center, 2471 TAMU, College Station, Texas 77843-2471, USA
}

Correspondence should be addressed to F W Bazer at Department of Animal Science, Center for Animal Biotechnology and Genomics, Texas A\&M University; Email: fbazer@cvm.tamu.edu

\begin{abstract}
Interferon $\tau$ (IFNT), the pregnancy recognition signal in ruminants, abrogates the luteolytic mechanism for maintenance of the corpus luteum for production of progesterone $\left(\mathrm{P}_{4}\right)$. This study examined the expression of DEAD (Asp-Glu-Ala-Asp) box polypeptide 58 (DDX58) and phospholipid scramblase 1 (PLSCR1) mRNAs in the ovine uterus as these genes were increased most in 2fTGH (STAT1 positive) cells by IFNT. The results of this study indicated that IFNT regulates expression of DDX58 and PLSCR1 mRNAs in the ovine uterus, which confirmed the results of the in vitro transcriptional profiling experiment with the 2fTGH (parental STAT1 positive) and U3A (STAT1 null) cell lines. Steady-state levels of DDX58 and PLSCR1 mRNAs increased in cells of the ovine uterus between days 12 and 20 of pregnancy, but not between days 10 and 16 of the estrous cycle. The expression of DDX58 and PLSCR1 mRNAs was greatest in endometrial stromal cells, but there was transient expression in uterine luminal and superficial glandular epithelial cells. $\mathbf{P}_{\mathbf{4}}$ alone did not induce expression of DDX58 and PLSCR1 mRNAs; however, intrauterine injections of IFNT did induce expression of DDX58 and PLSCR1 mRNAs in the endometria of nonpregnant ewes independent of effects of $P_{4}$. These results indicate that IFNT induces expression of DDX58 and PLSCR1 in ovine endometrial cells via the classical STAT1-mediated cell signaling pathway. Based on their known biological effects, DDX58 and PLSCR1 are IFN-stimulated genes, which may increase the antiviral status of cells of the pregnant uterus to protect against viral infection and/or enhance secretion of type I IFNs that inhibit viral replication.

Reproduction (2011) 141 127-138
\end{abstract}

\section{Introduction}

Interferon $\tau$ (IFNT), the maternal recognition signal in ruminants (sheep, cattle, goats), is produced by mononuclear trophectoderm cells of peri-implantation conceptuses (embryo/fetus and associated membranes) to prevent the development of the endometrial luteolytic mechanism (Bazer et al. 2010). IFNT is secreted by ovine trophectoderm cells between days 10 and 21 to 25 of pregnancy (Ashworth \& Bazer 1989) with maximal production between days 14 and 16 (Farin et al. 1989, Roberts et al. 1999). As a novel member of the type I IFN family, IFNT also possesses antiviral, antiproliferative, and immunomodulatory activities (Pontzer et al. 1991, Alexenko et al. 1997, Khan et al. 1998, Johnson et al. 1999c). In the ovine uterus, IFNT acts in a paracrine manner on endometrial luminal (LE) and superficial glandular epithelia (sGE) to suppress transcription of estrogen receptor $\alpha$ and oxytocin (OXT) receptor (Spencer \& Bazer 1996, Fleming et al. 2001), thereby preventing endometrial release of OXT-induced luteolytic pulses of prostaglandin $\mathrm{F}_{2 \alpha}$ (Bazer 1992, Spencer et al. 2004). The antiluteolytic action of IFNT allows maintenance of a functional corpus luteum and its secretion of progesterone $\left(\mathrm{P}_{4}\right)$, the hormone of pregnancy, which is required for successful establishment and maintenance of pregnancy (Spencer et al. 2004, Bazer et al. 2010). In addition to its antiluteolytic actions, IFNT increases expression of several IFNstimulated genes (ISGs) that are hypothesized to be important for endometrial differentiation and implantation of the conceptus (Hansen et al. 1999, Bazer et al. 2010). These ISGs include STAT1 and STAT2 (Johnson et al. 1999a, 1999d, Stewart et al. 2001a), IFN regulatory factor-1 (IRF1; Spencer et al. 1998, Johnson et al. 1999a, 1999d, Stewart et al. 2001a), IRF9 (Stewart et al. 2002), ISG15 (Johnson et al. 1999a, 1999b, 1999d, 2000, Stewart et al. 2001a), MX (Ott et al. 1998), OAS (Mirando et al. 1991, Johnson et al. 2001), MIC (Choi et al. 2003), B2M (Vallet et al. 1991, Choi et al. 2003), LGALS15 (Gray et al. 2004), WNT7A (Kim et al. 2003), 
CTSL1 (Song et al. 2005), CST3 (Song et al. 2006b), RSAD2, and IFIH1 (Song et al. 2007).

Available evidence indicates that IFNT induces dimerization of type I IFN receptors in cells of the ovine uterus (Han et al. 1997), and hence, phosphorylation of receptor-activated STATs (Johnson et al. 1999a, 1999d, Stewart et al. 2001a, 2001b) leading to formation of two transcription factor complexes: ISG factor 3 (ISGF3; STAT1:STAT2:IRF9 complex) and $\gamma$-activation factor (GAF; STAT1 homodimer; Stewart et al. 2001a, $2001 b$ ). Those transcription factor complexes translocate to the nucleus and bind to specific DNA sequences to activate transcription of target genes (Decker et al. 1991, Shuai et al. 1992, Pine et al. 1994). For example, GAF (Decker et al. 1991, Shuai et al. 1992) regulates transcriptional activities of genes containing a $\gamma$-activation sequence, such as IRF1 (Pine et al. 1994). In contrast, ISGF3 (Schindler et al. 1992) regulates transcription of genes containing IFN-stimulated response elements (ISREs), such as STAT1, STAT2, IRF9, and OAS (Reich et al. 1987, Levy et al. 1988). In the ovine uterus, IRF1 is a transcriptional activator that binds to both ISREs and IRF elements (Fujita et al. 1988, Harada et al. 1989, 1990, 1994, Karin 1991, Stark \& Kerr 1992, Nguyen et al. 1997, Mamane et al. 1999). In contrast, IRF2 is a potent transcriptional repressor (Senger et al. 2000). IRF2 is constitutively expressed in the ovine endometrial LE (oLE) and SGE, but increases during early pregnancy to prevent induction or increased expression of classical (STAT1 dependent) IFNT-stimulated genes (Choi et al. 2001). Therefore, classical IFNTstimulated genes are expressed by endometrial stromal cells and middle to deep uterine GE cells of the ovine uterus (Johnson et al. 2000, 2001, Choi et al. 2001, 2003). However, $P_{4}$ and/or IFNT act to induce and regulate expression of a novel set of genes in uterine LE and SGE via an unidentified novel cell signaling pathway(s) as these cells lack both $\mathrm{P}_{4}$ receptors (PGR) and STAT1 (Bazer et al. 2010).

It has been reported that the $2 \mathrm{fTGH}$ (parental) cells derived from a human fibrosarcoma and STAT1-null U3A cells derived from the $2 \mathrm{fTGH}$ parental cells are models for assessing the effects of IFNT on STAT1-dependent and STAT1-independent gene expressions respectively (Shuai et al. 1992, Stewart et al. 2002, Kim et al. 2003). These cells recapitulate cell-type-specific responses of the ovine uterus to IFNT in terms of IFNT signaling and ISG expression (Johnson et al. 1999 b, 2000, 2001, 2002, Choi et al. 2001, 2003). Therefore, these cells were used to determine the effects of IFNT on expression of DEAD (Asp-Glu-Ala-Asp) box polypeptide 58 (DDX58). DDX58 is a member of DExH box family that consists of two caspase recruitment domains (CARDs) at the $\mathrm{N}$-terminus and an RNA helicase domain at the C-terminus (Sun 1997, Wu et al. 2000) as they were the two genes most highly upregulated in 2fTGH cells by IFNT. It also contains the conserved DEAD motif as a putative RNA helicase induced by retinoic acid in differentiating promyelocytic leukemia cells (Sun 1997). Full-length DDX58 interacts with intracellular doublestranded RNA (dsRNA) to augment type I IFN production in response to viral infection in an ATP-dependent manner and CARD of DDX58 activates IRF3 and nuclear factor $\kappa-B$, subunit 1 (NFKB1; Yoneyama et al. 2004). Furthermore, DDX58 is induced by IFNG and regulates chemokine, CXC motif, ligand 11 (CXCL11) production in human cervical cancer cell lines and normal human endometrium (Yuzawa et al. 2008). Phospholipid scramblase 1 (PLSCR1) is an endofacial plasma membrane protein that mediates calcium-dependent transbilayer movement of membrane phospholipids. It was identified as an ISG in oligonucleotide array analyses and is required for maximal antiviral activity of type I IFNs (Basse et al. 1996, Zhou et al. 1997, Der et al. 1998, Dong et al. 2004). In the uteri of pregnant rats, there are two isoforms of PLSCRs, but this is not the case for PLSCR1 (Phillippe et al. 2006).

The expression of DDX58 and PLSCR1 genes in the ovine uterus with respect to temporal and cell-specific changes during the estrous cycle and early pregnancy, and in response to $\mathrm{P}_{4}$ and IFNT is not known. However, they are ISGs that can increase the antiviral state of cells to protect them from viral infection. Therefore, our working hypothesis was that DDX58 and PLSCR1 are induced in the ovine uterus in a cell-type-specific manner by IFNT from the conceptus during early pregnancy to mediate biological effects relative to the establishment of uterine receptivity to implantation by the ovine conceptus. Accordingly, this study was conducted to 1 ) identify ISGs induced by recombinant ovine IFNT (rolFNT) in cells expressing STAT1 (human 2fTGH cells) or not expressing STAT1 (U3A STAT1-null 2fTGH cells) and 2) determine the effects of the estrous cycle, pregnancy, and rolFNT on expression of DDX58 and PLSCR1 in the ovine uterus.

\section{Results}

\section{Upregulated genes in 2fTGH cells by rolFNT}

In this study, we have used 2fTGH (parental) cells derived from a human fibrosarcoma and STAT1-null U3A cells derived from the $2 \mathrm{fTGH}$ parental cells to assess the effects of IFNT on STAT1-dependent and STAT1-independent gene expressions respectively (Shuai et al. 1992, Stewart et al. 2002, Kim et al. 2003). These cells recapitulate cell-type-specific responses of the ovine uterus to IFNT in terms of IFNT signaling and ISG expression (Johnson et al. 1999b, 2000, 2001, 2002, Choi et al. 2001, 2003). Real-time quantitative PCR was used to identify the effects of rolFNT on expression of selected genes in 2fTGH cells, including DDX58, PLSCR1, bHLH factor HES4, PKD2, GALBP3, ANKFY1, FGF1A, and MYCL1 (Table 1). The analyses revealed that rolFNT increased 
Table 1 Real-time RT-PCR analysis of mRNA expression in 2fTGH and $\mathrm{U} 3 \mathrm{~A}$ cells treated with recombinant ovine interferon $\tau$ (rolFNT).

\begin{tabular}{lcc}
\hline Genes & $\begin{array}{c}\text { 2fTGH (none versus IFNT) } \\
\text { Fold increase }\end{array}$ & $\begin{array}{c}\text { U3A (none versus IFNT) } \\
\text { Fold increase }\end{array}$ \\
\hline DDX58 & $+26.2^{*}$ & $+3.34^{+}$ \\
PLSCR1 & $+5.5^{*}$ & $+2.0^{+}$ \\
GALBP3 & $+2.4^{+}$ & +1.6 \\
MYCL1 & $+1.5^{+}$ & $+1.9^{+}$ \\
TGFBR1 & -1.3 & +1.4 \\
ANKFY1 & $+1.8^{+}$ & +1.4 \\
HES4 & $+4.2^{*}$ & -1.5 \\
BRDT & +1.2 & $+1.7^{\ddagger}$ \\
PKD2 & $+3.2^{*}$ & +1.3 \\
FGF1A & $+1.8^{+}$ & +3.2 \\
CGREF1 & $+1.8^{\ddagger}$ & +1.0 \\
DHX33 & -1.0 & +1.0 \\
MMP23 & $+3.1^{+}$ & +1.2 \\
HOXD3 & +1.6 & +1.6 \\
\hline
\end{tabular}

${ }^{*} P<0.001 ;{ }^{\dagger} P<0.01 ;{ }^{\ddagger} P<0.05$. Real-time quantitative RT-PCR was used to determine fold increases in target gene mRNAs in 2fTGH and U3A control cells and in cells treated with roIFNT. The values presented are from independent experiments, each conducted in triplicate.

expression of DDX58 (26.2-fold), PLSCR1 (5.5-fold), HES4 (4.2-fold), and PKD2 (3.2-fold) $(P<0.001)$; MMP23 (3.1-fold), GALBP3 (2.4-fold), ANKFY1 (1.8-fold), FGF1A (1.8-fold), and MYCL1 (1.5-fold) $(P<0.01)$; and CGREF1 $(1.8$-fold $)(P<0.05)$ mRNAs in 2 fTGH cells. However, RT-PCR analyses for these genes in U3A (STAT1 deficient) cells indicated that rolFNT did not increase expression of DDX58 and PLSCR1 mRNAs.

\section{Western blot analyses for DDX58 and PLSCR1 proteins in 2fTGH and U3A cells treated with roIFNT in a time-dependent manner}

Parental $2 \mathrm{fTGH}$ and $\mathrm{U} 3 \mathrm{~A}$ cells were treated with rolFNT for $0,6,12$, or $24 \mathrm{~h}$. Western blot analyses of whole cell extracts detected immunoreactive DDX58 ( 110 kDa) and PLSCR1 (about $35.1 \mathrm{kDa}$ ) in both the cell lines, but the abundance of these proteins increased $(P<0.01)$ in response to IFNT only in $2 \mathrm{fTGH}$ cells in a time-dependent manner (Fig. 1). This indicates that the rolFNT induced increase in DDX58 and PLSCR1 mRNAs and proteins was STAT1 dependent. Also of interest were reports that DDX58 and PLSCR1 are expressed in HeLa cells and in rat uteri (Phillippe et al. 2006, Yuzawa et al. 2008). Therefore, we hypothesize that DDX58 and PLSCR 1 genes are induced in the ovine uterus in a cell-typespecific and STAT1-dependent manner by IFNT from the conceptus during early pregnancy to affect uterine receptivity to implantation by the ovine conceptus.

\section{DDX58 and PLSCR1 expression increases in ovine endometria in a cell-type-specific manner}

Partial cDNAs for ovine DDX58 and PLSCR 1 mRNAs were amplified by RT-PCR using total RNA from endometria collected on days 16 and 18 of pregnancy and specific primers (Table 2). The cDNAs were cloned and sequences were verified (data not shown). Steadystate levels of DDX58 and PLSCR 1 mRNAs in uterine endometria from cyclic and pregnant ewes, determined by slot blot hybridization analyses (Fig. 2), were affected by day $(P<0.01)$, pregnancy status $(P<0.01)$, and day by pregnancy status interaction $(P<0.01)$. The expression of DDX58 and PLSCR1 mRNAs in the endometria of cyclic ewes was low and not affected $(P>0.10)$ by day of the estrous cycle. However, expression of DDX58 mRNA increased $(P<0.01) 3.54$ fold between days 10 and 16, and then declined slightly to day 20 of pregnancy. The expression of PLSCR 1 mRNA also increased $(P<0.01)$ about 4.92 -fold between days 10 and 18 of pregnancy. In situ hybridization analyses revealed cell-specific expression of DDX58 and PLSCR 1 mRNAs in uteri of cyclic and pregnant ewes (Figs 3 and 4). The expression of DDX58 mRNA in uterine LE was not different between day 10 cyclic and day 10 pregnant ewes, but between days 12 and 16 of pregnancy, DDX58 mRNA increased in stromal cells, but was undetectable in LE and sGE (Fig. 3). In cyclic ewes, PLSCR1 mRNA was detected in endometrial LE and SGE on days 10 and 12 and at very low abundance between days 14 and 16 of the estrous cycle (Fig. 4). Similarly, in pregnant ewes, PLSCR 1 mRNA was detected mainly in LE and sGE on days 10 and 12 and then increased in abundance in stratum compactum stroma and SGE between days 14 and 20 of pregnancy.

\section{Intrauterine administration of rolFNT increases DDX58 and PLSCR1 mRNAs in the endometrium}

In order to determine whether the differences in the expression of DDX58 and PLSCR 1 genes in the uteri of pregnant compared with cyclic ewes were due to IFNT from the conceptus, cyclic ewes were ovariectomized and fitted with intrauterine (i.u.) catheters on day 5 after the onset of estrus. The ewes received daily i.m. injections of $25 \mathrm{mg} \mathrm{P}_{4}$ from day 5 until they were

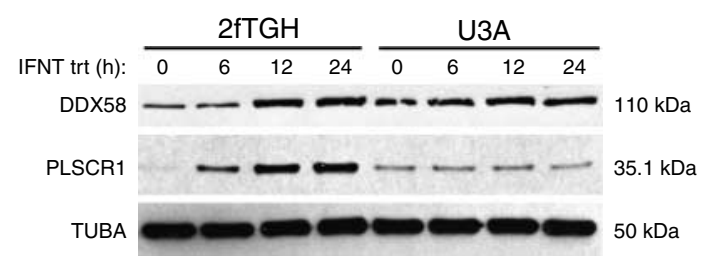

Figure 1 Detection of immunoreactive DDX58 and PLSCR1 proteins in human 2fTGH (parental) and U3A (STAT1-null 2fTGH) cell lines. Cells were treated with rolFNT $\left(10^{4} \mathrm{AVU} / \mathrm{ml}\right)$ for $0,6,12$, or $24 \mathrm{~h}$ in each of three independent experiments. These results indicate that induction of DDX58 and PLSCR1 by rolFNT is STAT1 dependent. Immunoreactive proteins were detected using rabbit anti-DDX58 and anti-PLSCR1 antibodies and compared with the levels of mouse $\alpha$-tubulin (TUBA) protein as a loading control. 
Table 2 Sequences of primers used for real-time RT-PCR and cloning.

\begin{tabular}{|c|c|c|c|}
\hline Genes & Sequence $\left(5^{\prime}-3^{\prime}\right)$ : forward and reverse & GenBank accession & Product size $(b p$ \\
\hline \multicolumn{4}{|c|}{ For real-time PCR } \\
\hline \multirow[t]{2}{*}{ DDX58 } & GGAAGACCCTGGACССТАCСТ & NM_014314 & 72 \\
\hline & TATACTGCAССТСТТССТСССТААА & & \\
\hline \multirow[t]{2}{*}{ PLSCR1 } & GAATGCTTCTCACCCGGAAA & NM_021105 & 82 \\
\hline & TCCTGGAGGTCCTTGGAATG & & \\
\hline \multirow[t]{2}{*}{ PKD2 } & AGCAGCTGGCCTGTTCCAT & AF309082 & 71 \\
\hline & GATCTTGTCGTAAAGGCCGTAGA & & \\
\hline \multirow[t]{2}{*}{ GALBP3 } & СТСАСТGGCСGАСТGСАA & NM_005567 & 97 \\
\hline & GGTGCTCCTGGTTTCATTGGT & & \\
\hline \multirow[t]{2}{*}{ ANKFY1 } & CAGCAGCGAGTCCTTCATCA & NM_016376 & 70 \\
\hline & GCTGTACTGCTCCTGCTCGTAGA & & \\
\hline \multirow[t]{2}{*}{ HES4 } & TGGACGCССТСAGAAAAGAG & NM_021170 & 74 \\
\hline & TCTCACGGTCATCTCCAGGAT & & \\
\hline \multirow[t]{2}{*}{ FGF1A } & GGACACCGACGGGCTTTTAT & NM_000800 & 69 \\
\hline & TCCAGCСТTTCCAGGAACAA & & \\
\hline \multirow{2}{*}{ MYCL1 } & CGGAAGCCGGTCACCAT & X07263 & 66 \\
\hline & GATGTGGAAATGCTTCATGCA & & \\
\hline \multirow{2}{*}{ CGREF1 } & TCAGGCTGCCCCAAAGG & NM_006569 & 65 \\
\hline & TGGGCAGGAGCTGATGCT & & \\
\hline \multirow[t]{2}{*}{$B R D T$} & GTACTTGTAGACAGGATTCAAAGCAGTT & NM_001726 & 83 \\
\hline & TGGTGGAGGAGGGTTAACAATAA & & \\
\hline \multirow[t]{2}{*}{ TGFBR1 } & CGAGATAGGCCGTTTGTATGTG & NM_004612 & 82 \\
\hline & TGCAATGGTCCTGATTGCA & & \\
\hline \multirow[t]{2}{*}{ DHX33 } & GGCTCTGGGAAGACAACTCAGA & NM_020162 & 82 \\
\hline & GCTGGGTCACAGCAATGATG & & \\
\hline \multirow[t]{2}{*}{ MMP23 } & CAGGCTGGTGCCCGAG & NM_004659 & 74 \\
\hline & АСАСТTTCССТTTCTTGTGGAGG & & \\
\hline \multirow[t]{2}{*}{ HOXD3 } & ССТGССАAGAAGCССАAАG & Y09980 & 70 \\
\hline & GGAAGATCTGCTTGCTGATGGT & & \\
\hline \multirow[t]{2}{*}{ CYC. B } & GACAAGGTCCCAAAGACAGC & NM_000942 & 69 \\
\hline & TCGAGTTGTCCACAGTCAGC & & \\
\hline \multicolumn{4}{|l|}{ For RT-PCR } \\
\hline \multirow[t]{2}{*}{$D D \times 58$} & ACCAGAGGCAGAGGAAGAGC & NM_014314 & 450 \\
\hline & ATGGATTCCCCAGTCATGG & & \\
\hline \multirow{2}{*}{ PLSCR1 } & GCAGCAGAGGATACTGATTGC & NM_021105 & 484 \\
\hline & TGAAGTCAATGAGGAAACATGC & & \\
\hline
\end{tabular}

DDX58 (=RIG-1), retinoic acid-inducible gene 1; PLSCR1, phospholipid scramblase 1; PKD2, protein kinase D2; GALBP3, galactoside-binding, soluble, 3 binding protein; ANKFY1, ANKHZN protein (ankyrin repeat and FYVE domain containing 1); HES4, bHLH factor Hes4; FGF1A, FGF-1 acidic-like protein; MYCL1, v-myc myelocytomatosis viral oncogene homolog 1; CGREF1, cell growth regulator with EF hand domain 1; BRDT, a testis-specific bromodomain-containing protein; TGFBR1, TGFB receptor 1; DHX33, DEAH (Asp-Glu-Ala-His) box polypeptide 33; MMP23, matrix metalloproteinase 23A; HOXD3, homeobox D3.

hysterectomized on day 16 . The treatment groups were as follows 1) $\mathrm{P}_{4}$ from days 5 to 16 and i.u. injections of control serum proteins $(\mathrm{CX}, 200 \mu \mathrm{g})$ at 0700 and $1700 \mathrm{~h}$ on days $\left.11-16\left(\mathrm{P}_{4}+\mathrm{CX}\right) ; 2\right)$ i.m. $\mathrm{P}_{4}$, i.u. $\mathrm{CX}$ proteins, and $75 \mathrm{mg}$ ZK $136317\left(\mathrm{ZK}, \mathrm{P}_{4}\right.$ receptor antagonist) from days 11 to $\left.16\left(\mathrm{P}_{4}+\mathrm{CX}+\mathrm{ZK}\right) ; 3\right)$ i.m. $\mathrm{P}_{4}$ and i.u. rolFNT $\left(1 \times 10^{8}\right.$ antiviral units $(\mathrm{AVU}) /$ day $)$ from days 11 to $16\left(\mathrm{P}_{4}+\right.$ IFNT); and 4) i.m. $\mathrm{P}_{4}$, i.u. rolFNT, and $75 \mathrm{mg}$ ZK $136317 \quad\left(\mathrm{P}_{4}+\mathrm{IFNT}+\mathrm{ZK}\right)$. Intrauterine administration of rolFNT increased expression of DDX58 and PLSCR 1 mRNAs by sixand tenfold respectively in the endometrium of ewes $\left(\mathrm{P}_{4}+\mathrm{CX}\right.$ versus $\mathrm{P}_{4}+\mathrm{IFN}, P<0.001$; Fig. $5 \mathrm{~A}$ and $\left.\mathrm{B}\right)$. Similarly, i.u. injections of rolFNT increased DDX58 and PLSCR $1 \mathrm{mRNAs}$ by four- and fourfold respectively in ewes treated with $Z K\left(\mathrm{P}_{4}+\mathrm{ZK}+\mathrm{CX}\right.$ versus $\mathrm{P}_{4}+\mathrm{ZK}+$ IFN, $P<0.001$ ) indicating an effect of rolFNT, which was independent of functional PGR. In situ hybridization analyses verified that rolFNT increased DDX58 and PLSCR1 mRNA expression in a cell-type-specific manner consistent with that observed in uteri from ewes on days 16 and 18 of pregnancy. The i.u. rolFNT increased both DDX58 and PLSCR 1 mRNAs in stromal cells (Fig. 5C and D), but not in LE, GE, blood vessels, or myometrium $(P>0.05)$.

\section{Effects of IFNT on DDX58 and PLSCR1 in endometrial cells}

As compared with untreated ovine stromal cells maintained in serum-free medium, treatment with rolFNT for $0,6,12$, or $24 \mathrm{~h}$ increased $(P<0.001)$ or induced expression of DDX58 and PLSCR 1 mRNAs (Fig. 6A-C). In addition, as compared with untreated oLE and bovine endometrial (BEND) cells maintained in serum-free medium, treatment of both oLE and BEND cells with rolFNT increased $(P<0.001)$ or induced expression of DDX58 and PLSCR1 mRNAs (Fig. 7A-C). 

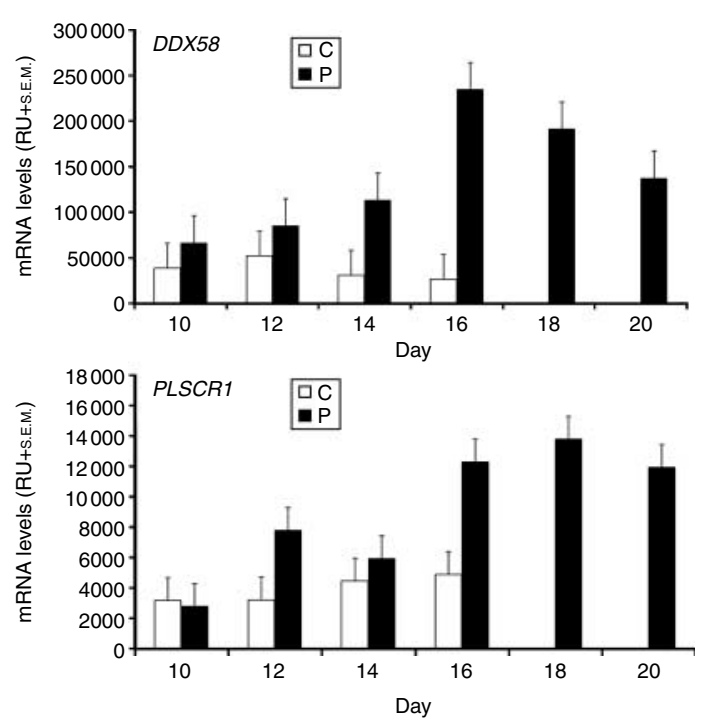

Figure 2 Steady-state levels of DDX58 and PLSCR 1 mRNAs in endometria from cyclic $(C)$ and pregnant $(P)$ ewes (study one). Significant $(P<0.01)$ changes in expression of DDX58 and PLSCR1 were due to day, pregnancy status, and day by pregnancy status interaction. Expression of DDX58 mRNA increased about 3.5-fold between days 10 and 16 , and then declined slightly to day 20 . In cyclic ewes, there was no effect $(P>0.10)$ of day of the estrous cycle. PLSCR1 mRNA increased about 4.9-fold between days 10 and 18 of pregnancy, but there was no effect $(P>0.10)$ of day of the estrous cycle. Data are expressed as least square means (LSM) relative units (RU) with S.E.M.

\section{Discussion}

In this study, expression of DDX58 and PLSCR1 genes in the ovine endometrium were regulated by IFNT in an STAT1-dependent manner that was independent of functional PGR and $\mathrm{P}_{4}$. Implantation and establishment of pregnancy require that the peri-implantation ruminant conceptuses enter a receptive uterus and secrete IFNT (Bazer \& Roberts 1983, Spencer et al. 1996, Bazer et al. 1998, 2010). Ovine IFNT prevents development of the luteolytic mechanism in the endometrium and acts as a pregnancy recognition signal, which communicates between the conceptus and maternal endometrium to allow for the establishment and maintenance of pregnancy, including implantation and synepitheliochorial placentation (Bazer et al. 1998, 2010). Furthermore, IFNT regulates the expression of ISGs that are considered essential for endometrial differentiation and implantation (Hansen et al. 1999, Bazer et al. 2010). Most classical IFNT-stimulated genes are expressed by endometrial stromal cells and middle to deep GE in the ovine uterus via STAT1-dependent cell signaling (Vallet et al. 1991, Shuai et al. 1992, Johnson et al. 1999b, Stewart et al. 2002). In ewes, IRF2 is a transcriptional repressor of STAT1 gene expression (Senger et al. 2000, Choi et al. 2001) that appears to be responsible for expression of a limited number of nonclassical ISGs (e.g. LGALS11, WNT7A, CTSL1, and CST3) by ovine uterine LE and SGE that are induced by $\mathrm{P}_{4}$ and further stimulated by IFNT via an unidentified cell signaling pathway(s) (Bazer et al. 2010) The STATs are required for classical signal transduction elicited by IFNT in ovine uterine stromal cells and GE because they interact with specific IFN-responsive elements and/or STAT-interacting transcription factors in the nucleus to modulate expression of defined target genes.

This study first identified DDX58 and PLSCR 1 as genes induced by ovine IFNT in human $2 \mathrm{fTGH}$ (parental), but not STAT1-null U3A cells by transcriptional profiling. Accordingly, we then determined the effects of the estrous cycle, pregnancy, and i.u. injections of rolFNT on expression of those genes. The $2 \mathrm{fTGH}$ and U3A cells recapitulated endometrial cell-type-specific responses to IFNT in terms of type I IFN-receptor-induced cell signaling and STAT1-dependent expression of several classical ISGs (Shuai et al.1992, Johnson et al. 1999b, 2000, 2001, 2002, Choi et al. 2001, 2003, Stewart et al. 2002). When 2fTGH and U3A cells were treated with IFNT, expression of PLSCR1 and DDX58 mRNAs and proteins was detected only in $2 \mathrm{fTGH}$ cells that expressed STAT1 (Fig. 1). These results indicate that genes responsive to IFNT in an STAT1-dependent manner can be identified in $2 \mathrm{fTGH}$ human fibroblast cells by transcriptional profiling and that the use of those cells for identification of genes potentially regulated by IFNT in the ovine endometrium during the peri-implantation period is valid as previously reported (Kim et al. 2003, Song et al. 2007).

This is the first known report of temporal and spatial alterations in expression of DDX58 and PLSCR 1 genes in the uteri of cyclic and pregnant ewes. On the basis of the results of this study, we tested the hypotheses to understand the biological roles of DDX48 and PLSCR 1 in the establishment and maintenance of pregnancy with particular emphasis on uterine receptivity to implantation by the ovine conceptus. Of interest is the increase in expression of these genes in the ovine endometrium that coordinates with maximum production of IFNT by the rapidly elongating ovine conceptus between days 13 and 16 of pregnancy (Ashworth \& Bazer 1989).

Most IFNT-stimulated genes are expressed by endometrial stromal cells and middle to deep GE in the ovine uterus (Vallet et al. 1989, 1991, Shuai et al. 1992, Johnson et al. 1999b, Stewart et al. 2002, Bazer et al. 2008). This is due to the fact that IRF2, a potent transcriptional repressor, is expressed in LE and sGE that lack STAT1 (Senger et al. 2000, Choi et al. 2001). In this study, the PLSCR1 and DDX58 genes were upregulated in stromal cells, but not in uterine LE or sGE during pregnancy. Full-length DDX58 interacts with intracellular dsRNA to augment type I IFN production in response to viral infection in an ATP-dependent manner, and CARD of DDX58 activates IRF3 and NFKB1 (Yoneyama et al. 2004). There is also evidence for an important role for DDX58 cell signaling in innate 


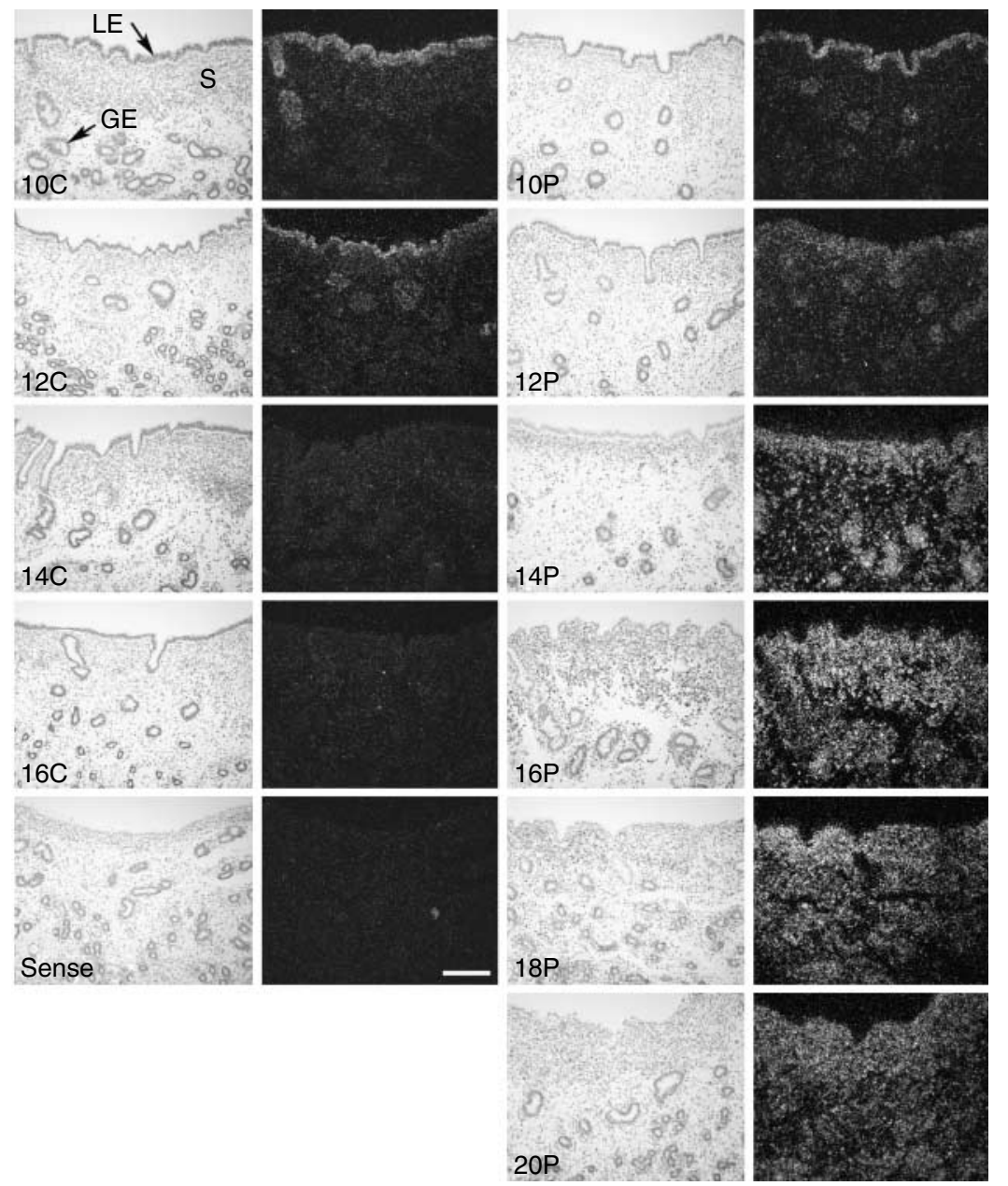

Figure 3 In situ hybridization analyses of DDX58 mRNA in the uteri of cyclic and pregnant ewes (study one). Cross sections of the uterine wall from cyclic (C) and pregnant $(\mathrm{P})$ ewes were hybridized with radiolabeled antisense or sense ovine DDX58 CRNA probes. Note the cell-specific changes in expression from LE and sGE to stromal cells and GE after day 12 of pregnancy. LE, luminal epithelium; GE, glandular epithelium; S, stromal cells. Bar represents $10 \mu \mathrm{m}$. intracellular defense against hepatitis $\mathrm{C}$ virus (Breiman et al. 2005, Foy et al. 2005, Li et al. 2005, Sumpter et al. 2005). DDX58 is expressed in endothelial cells (Imaizumi et al. 2004a), vascular smooth muscle cells (Imaizumi et al. 2004b), and MCF7 cells (Cui et al. 2004) in response to IFNG, lipopolysaccharide (Imaizumi et al. 2002), and interleukin $1 \beta$ (Sakaki et al. 2005).

In pregnant ewes, PLSCR 1 mRNA was detected in LE and SGE on days 10 and 12 , but primarily in the stratum compactum stroma and sGE between days 14 and 20 of pregnancy. PLSCR1 is an endofacial plasma membrane protein that mediates calcium-dependent transbilayer movement of membrane phospholipids (Basse et al. 1996, Zhou et al. 1997). It was identified as an ISG in oligonucleotide array analyses (Der et al. 1998) and found to be required for maximal antiviral activity of type I IFNs (Dong et al. 2004).

In conclusion, the results of this study are the first, to our knowledge, to indicate that pregnancy and IFNT increase expression of DDX58 and PLSCR1 in an STAT1dependent manner in ovine endometrial stromal cells, but not in uterine LE or GE during the peri-implantation period of pregnancy in ewes. The possibilities exist that DDX58 and PLSCR1 increase the antiviral state of the pregnant uterus to protect against viral infection and/or to enhance expression of type I IFNs that inhibit viral replication. These biological effects may be important in optimizing conditions for uterine receptivity to implantation and the establishment and maintenance of pregnancy in sheep.

\section{Materials and Methods}

\section{Animals}

Mature crossbred Suffolk ewes (Ovis aries) were observed daily for estrus in the presence of vasectomized rams and used in the experiment after they exhibited at least two estrous cycles of normal duration (16-18 days). At estrus, ewes were assigned randomly to cyclic or pregnancy status. All experimental and surgical procedures were in compliance with the Guide for the Care and Use of Agriculture Animals and approved by the Institutional Agricultural Animal Care and Use Committee of Texas A\&M University. 

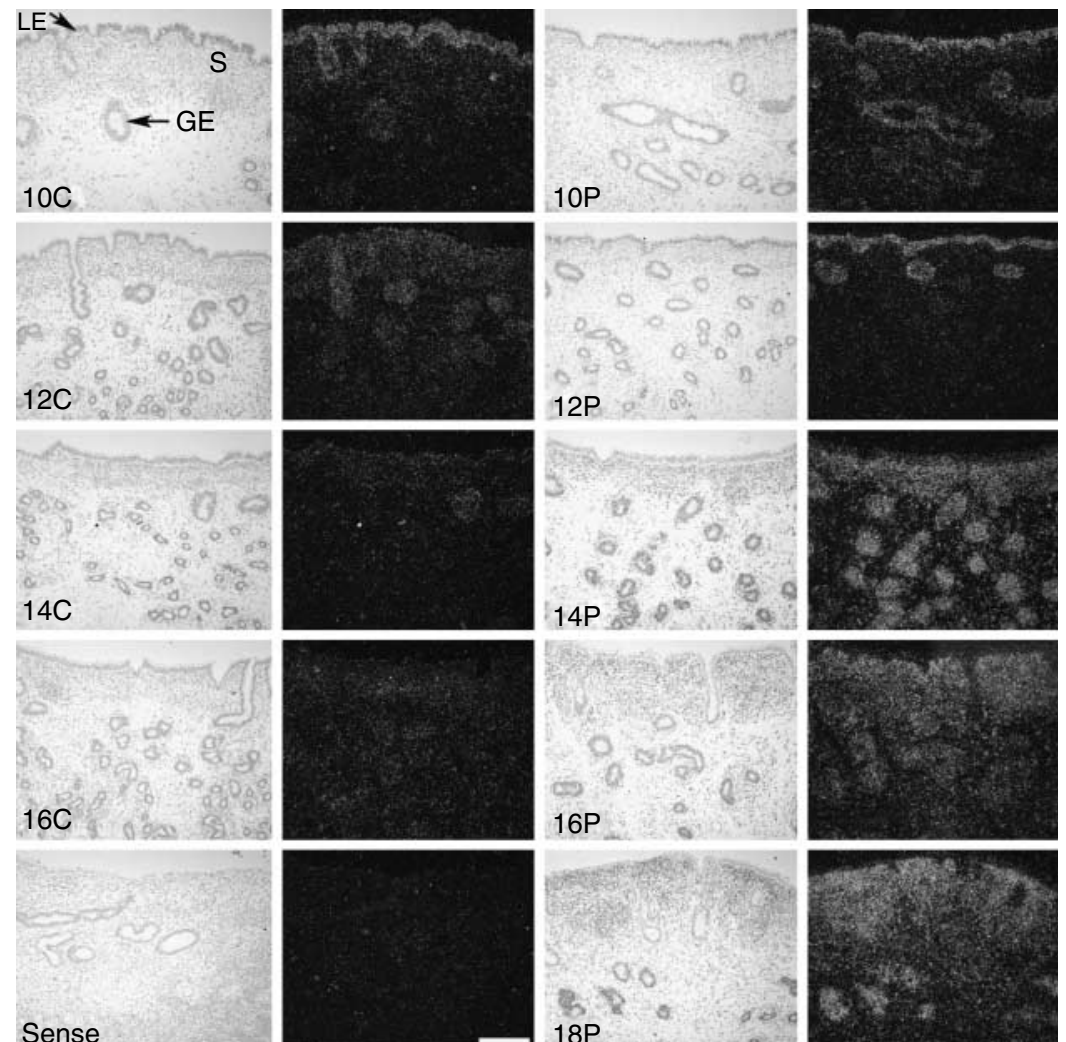

Sense
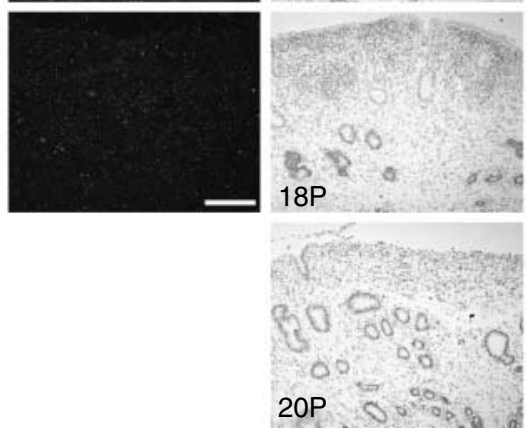

\section{Cell lines}

The 2fTGH (parental) and U3A (STAT1-null 2fTGH) cell lines were derived from a human fibrosarcoma and responded to both type I and type II IFNs (Pellegrini et al. 1989). The 2fTGH cells were maintained in basal medium containing DMEM with F-12 salts (DMEM-F12; Sigma-Aldrich Corp.) supplemented with $10 \%$ fetal bovine serum (FBS) and penicillin/ streptomycin/amphotericin solution (Invitrogen) as described previously (Stewart et al. 2001a, 2001b). The U3A cells were maintained in basal medium with hygromycin B $(250 \mu \mathrm{g} / \mathrm{ml}$; Invitrogen). rolFNT was prepared and assayed for biological activity as described previously (Van Heeke et al. 1996). The biological activity of rolFNT, expressed as AVU, was $1 \times 10^{9} \mathrm{AVU} / \mathrm{mg}$ protein. Monolayer cultures of $2 \mathrm{fTGH}$ and U3A cells were grown in culture medium to $80-90 \%$ confluency in $100 \mathrm{~mm}$ tissue culture plates $(n=3$ per treatment). Cells were either untreated to serve as a control or treated with rolFNT $\left(10^{4} \mathrm{AVU} / \mathrm{ml}\right)$ for $0,6,12$, or $24 \mathrm{~h}$ in each of three independent replicates. The dose of rolFNT used was known to induce or increase expression of several ISGs in ovine uterine endometrial cells and human $2 \mathrm{fTGH}$ and U3A cell lines (Stewart et al. 2001a, 2001b, Kim et al. 2003). Total RNA was isolated and used for transcriptional profiling or RT-PCR. This design was used in three independent replicates.
Immortalized ovine uterine endometrial LE cells were cultured as described previously (Johnson et al. 1999a, 1999d). BEND cells (Johnson et al. 1999b) were kindly provided by $\mathrm{Dr}$ Thomas R Hansen (Colorado State University, Fort Collins, CO, USA). Ovine LE and BEND cells were maintained in $150 \mathrm{~mm}$ culture dishes containing DMEM with F-12 salts (DMEM-F12; Sigma-Aldrich Corp.) supplemented with $5 \%$ FBS and antibiotics. When cells reached $70-80 \%$ confluency, they were treated with either rolFNT $\left(2 \times 10^{7} \mathrm{AVU} / \mathrm{ml}\right)$ or left untreated as a control for $24 \mathrm{~h}$ in serum-free medium. The experiment was independently repeated in three replicates for each cell type.

\section{Experimental design}

Study one

At estrus (day 0), ewes were mated to either intact or vasectomized rams and then hysterectomized ( $n=5$ ewes/day) on either day $10,12,14$, or 16 of the estrous cycle or day 10,12, $14,16,18$, or 20 of pregnancy as described previously (Spencer et al. 1999a). Pregnancy was confirmed on days 10-16 post mating by the presence of a morphologically normal conceptus(es) in the uterus. At hysterectomy, several sections $(\sim 0.5 \mathrm{~cm})$ from the mid-portion of each uterine horn ipsilateral 
A

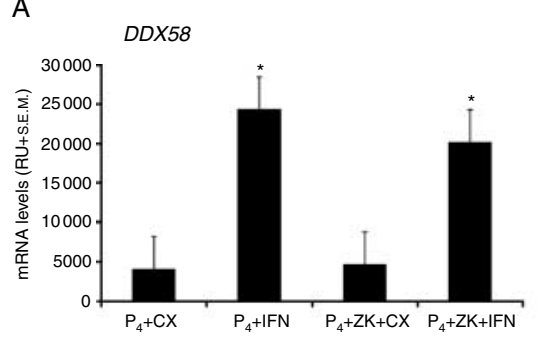

C

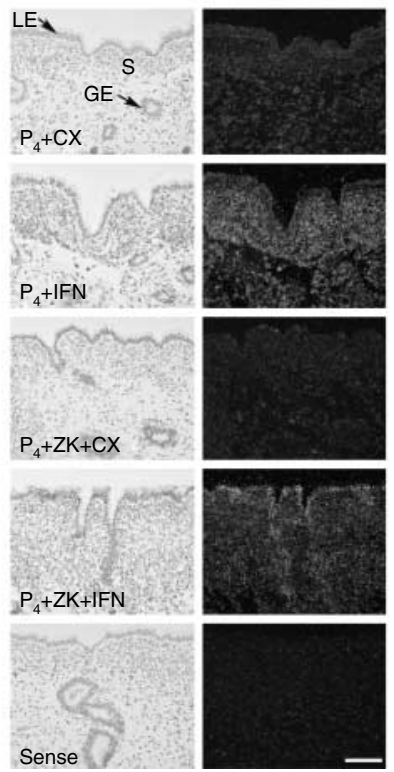

B

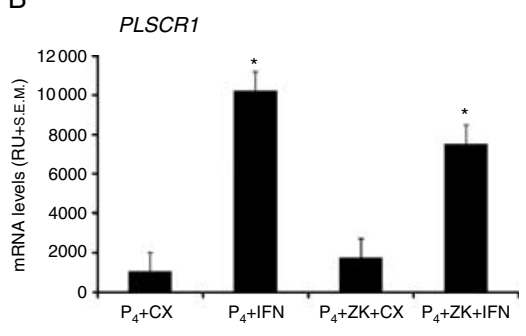

D

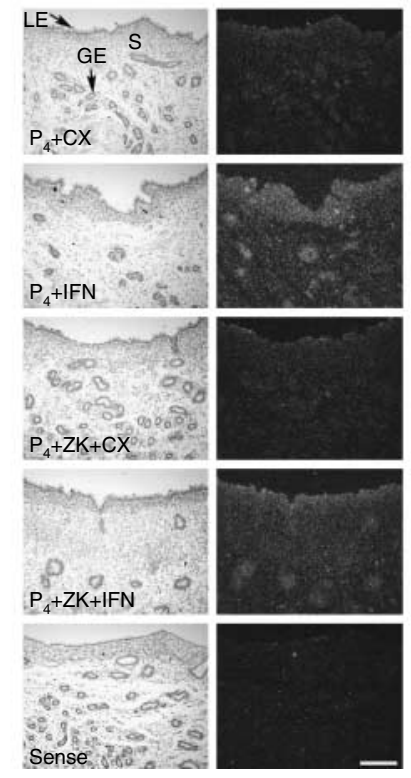

Figure 5 Effects of progesterone and rolFNT on DDX58 and PLSCR 1 mRNAs in ovine uterine endometria (study two). (A and B) Steady-state levels of DDX58 and PLSCR 1 mRNA in endometria were determined by slot blot hybridization analysis. The asterisk $\left({ }^{*}\right)$ denotes an effect of treatment. (C and D) In situ hybridization analysis of expression of DDX58 and PLSCR1 mRNAs indicated that both transcripts are induced by rolFNT in uterine stromal cells and GE. Cross sections of the uterine wall from ewes were hybridized with radiolabeled antisense or sense ovine DDX58 and PLSCR1 CRNA probes. LE, luminal epithelium; GE, glandular epithelium; $\mathrm{S}$, stromal cells; $\mathrm{P}_{4}$, progesterone; rolFNT, recombinant ovine IFNT; ZK, ZK 137 316; CX, control serum protein; IFN, interferon. Scale bar represents $10 \mu \mathrm{m}$. to the corpus luteum were fixed in fresh $4 \%$ paraformaldehyde in PBS ( $\mathrm{pH} 7.2$ ). After $24 \mathrm{~h}$, fixed tissues were changed to $70 \%$ ethanol for $24 \mathrm{~h}$ and then dehydrated and embedded in Paraplast-Plus (Oxford Labware, St Louis, MO, USA). Several sections $(1-1.5 \mathrm{~cm})$ from the middle of each uterine horn were embedded in Tissue-Tek OCT compound (Miles, Oneonta, NY, USA), frozen in liquid nitrogen vapor, and stored at $-80^{\circ} \mathrm{C}$. The remaining endometrium was physically dissected from myometrium, frozen in liquid nitrogen, and stored at $-80{ }^{\circ} \mathrm{C}$ for subsequent RNA extraction. In monovulatory pregnant ewes, uterine tissue samples were marked as either contralateral or ipsilateral to the ovary bearing the CL. No tissues from the contralateral uterine horn were used for this study.

\section{Study two}

In order to determine whether the differences in expression of DDX58 and PLSCR1 genes in the uteri of pregnant compared with cyclic ewes were due to IFNT from the conceptus, 16 cyclic ewes were ovariectomized and fitted with i.u. catheters on day 5 post estrus. Ewes were then assigned randomly ( $n=4$ ewes/ treatment) to receive daily i.m. injections of $\mathrm{P}_{4}$ between days 5 and 16, and either a PGR antagonist (ZK 136 317; Schering, Berlin-Wedding, Germany) or no PGR antagonist (ZK 136 317) and daily i.u. infusions of either control serum proteins or rolFNT protein between days 11 and 16 were as follows: 1) $25 \mathrm{mg} \mathrm{P}_{4}$ and $200 \mu \mathrm{g}$ control $(\mathrm{CX})$ serum proteins $\left(\mathrm{P}_{4}+\mathrm{CX}\right) ; 2$ ) $\mathrm{P}_{4}, 75 \mathrm{mg} Z \mathrm{ZK} 136$ 317, and CX proteins $\left.\left(\mathrm{P}_{4}+\mathrm{ZK}+\mathrm{CX}\right) ; 3\right) \mathrm{P}_{4}$ and
rolFNT $\left(1 \times 10^{8} \mathrm{AVU}\right)\left(\mathrm{P}_{4}+\mathrm{IFN}\right)$; or 4$) \mathrm{P}_{4}$, ZK 136317 , and rolFNT $\left(\mathrm{P}_{4}+\mathrm{ZK}+\mathrm{IFN}\right)$. All ewes were hysterectomized on day 16. At hysterectomy, several sections $(\sim 0.5 \mathrm{~cm})$ from the midportion of each uterine horn were fixed in fresh $4 \%$ paraformaldehyde in PBS ( $\mathrm{pH}$ 7.2). After $24 \mathrm{~h}$, fixed tissues were changed to $70 \%$ ethanol for $24 \mathrm{~h}$ and then dehydrated and embedded in Paraplast-Plus (Oxford Labware). Several sections $(1-1.5 \mathrm{~cm})$ from the middle of each uterine horn were embedded in Tissue-Tek OCT compound (Miles), frozen in liquid nitrogen vapor, and stored at $-80^{\circ} \mathrm{C}$. The remaining endometrium was physically dissected from myometrium, frozen in liquid nitrogen, and stored at $-80{ }^{\circ} \mathrm{C}$ for RNA extraction.

\section{RNA isolation}

Total cellular RNA was isolated from frozen ipsilateral endometrium (studies one and two) using Trizol reagent (Gibco-BRL) according to the manufacturer's recommendations. The quantity and quality of total RNA were determined by spectrometry and denaturing agarose gel electrophoresis respectively.

\section{Real-time quantitative RT-PCR analysis}

The cDNA was synthesized from total cellular RNA $(5 \mu \mathrm{g})$ isolated from cells using random primers (Invitrogen), oligo(dT) primers, and SuperScript II Reverse Transcriptase (Invitrogen) as 

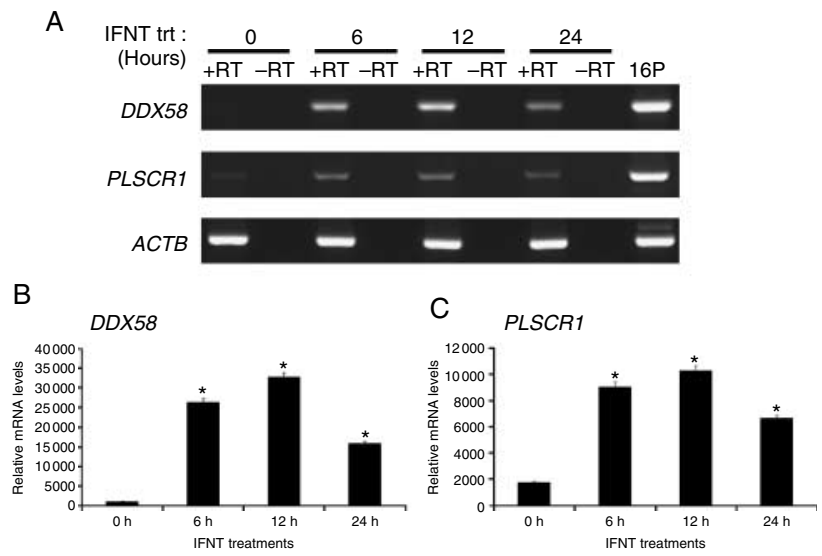

Figure 6 Semiquantitative RT-PCR analyses of DDX58 and PLSCR1 mRNAs in total cellular RNA isolated from immortalized ovine endometrial stromal cells. Cells were treated with rolFNT $\left(10^{4} \mathrm{AVU} / \mathrm{ml}\right)$ for $0,6,12$, or $24 \mathrm{~h}$ in each of three independent experiments. (A) All PCR products were separated in a $1.5 \%$ agarose gel and stained with ethidium bromide. Total cellular RNA from the endometria of a day-16 pregnant ewe and sterile water (no template) were taken as positive and negative controls respectively. ( $\mathrm{B}$ and $\mathrm{C}$ ) A graph illustrating the effect of IFNT on relative mRNA levels for DDX58 and PLSCR 1 is presented below each gel, and the asterisk $\left(^{*}\right)$ denotes a significant $(P<0.001)$ effect of IFNT treatment.

described previously (Song et al. 2007). Newly synthesized cDNA was acid-ethanol precipitated, resuspended in $20 \mu \mathrm{l}$ of water, and stored at $-20{ }^{\circ} \mathrm{C}$. Real-time PCR was performed using an ABI PRISM 7700 (Applied Biosystems, Foster City, CA, USA) with SYBR Green PCR Master Mix (Applied Biosystems) as the detector according to the manufacturer's recommendations. Primers were designed to amplify cDNAs of $<200 \mathrm{bp}$ to maximize efficiency (Table 2). PCR cycle parameters were $95{ }^{\circ} \mathrm{C}$ for $15 \mathrm{~s}$ and $60{ }^{\circ} \mathrm{C}$ for $1 \mathrm{~min}$ for 35 cycles. Data were analyzed using GeneAmp 5700 SDS software (version 1.4). The threshold line was set in the linear region of the plots above the baseline noise, and threshold cycle $\left(C_{\mathrm{t}}\right)$ values were determined as the cycle number at which the threshold line crossed the amplification curve. The results are expressed in terms of change in $C_{\mathrm{t}}$ values $\left(\Delta C_{\mathrm{t}}\right)$, which refer to the cycle number during exponential amplification at which the PCR product (measured in real-time by SYBR green fluorescence) crossed a set threshold. To adjust for variations in the amount of input RNA/cDNA, the average $C_{\mathrm{t}}$ values for each gene were normalized against average $C_{\mathrm{t}}$ values for the housekeeping gene (peptidyl-prolyl isomerase B, PPIB; Dioum et al. 2009) as follows: $\Delta C_{\mathrm{t}}=$ average $C_{\mathrm{t}}$ specific gene - average $C_{\mathrm{t}}$ СуpC. This is subtraction of an arbitrary constant, so the S.D. of $\Delta \Delta C_{\mathrm{t}}$ is the same as the S.D. of the $\Delta C_{\mathrm{t}}$ value. Finally, the relative value of each mRNA was calculated by the formula: $2^{-\Delta \Delta C_{t}}$. The PCR without template or template substituted with total RNA was used as a negative control to verify experimental results.

\section{Cloning of partial cDNAs for ovine DDX58 and PLSCR1}

Partial cDNAs for ovine DDX58 and PLSCR1 mRNAs were amplified by RT-PCR using total RNA endometrial tissues from days 18 of pregnancy using specific primers (Table 2). RT of cellular total RNA into cDNA was performed as described previously (Song et al. 2006a). PCR amplification was conducted as follows for DDX58 and PLSCR1: 1) $95^{\circ} \mathrm{C}$ for 5 min; 2) $95{ }^{\circ} \mathrm{C}$ for $30 \mathrm{~s}, 56{ }^{\circ} \mathrm{C}$ for $40 \mathrm{~s}$ (for DDX58), $64.5^{\circ} \mathrm{C}$ for $40 \mathrm{~s}$ (for PLSCR1), and $72{ }^{\circ} \mathrm{C}$ for $1 \mathrm{~min}$ for 35 cycles; and 3) $72{ }^{\circ} \mathrm{C}$ for $10 \mathrm{~min}$. The partial cDNAs for ovine DDX58 and PLSCR1 PCR products were cloned into pCRII using a T/A Cloning kit (Invitrogen) and their sequences were verified using an ABI PRISM Dye Terminator Cycle Sequencing kit and ABI PRISM automated DNA sequencer (Perkin-Elmer Applied Biosystems, Norwalk, CT, USA).

\section{Slot blot hybridization analyses}

Steady-state levels of mRNA in ovine endometria were assessed by slot blot hybridization as described previously (Spencer et al. 1999b, Song et al. 2006a). For DDX58 and PLSCR1, antisense cRNA probes were generated by linearizing the pCRII-DDX58/-PLSCR1 plasmid with Xbal and in vitro transcription with SP6 RNA polymerase and sense cRNA probes were generated using BamHI and T7 RNA polymerase. Radiolabeled antisense and sense cRNA probes were then generated by in vitro transcription with $\left[\alpha_{-}^{32} \mathrm{P}\right]-U T P$. Denatured total endometrial RNA $(20 \mu \mathrm{g})$ from each ewe was hybridized with radiolabeled cRNA probes. To correct for variation in total RNA loading, a duplicate RNA slot membrane was hybridized with radiolabeled antisense 18S cRNA (pT718S; Ambion, Austin, TX, USA). Following washing, the blots were digested with RNase A and radioactivity associated with slots quantified using a Typhoon 8600 Multilmager (Molecular Dynamics, Piscataway, NJ, USA).

A

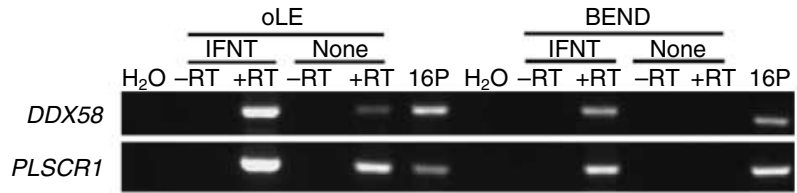

B

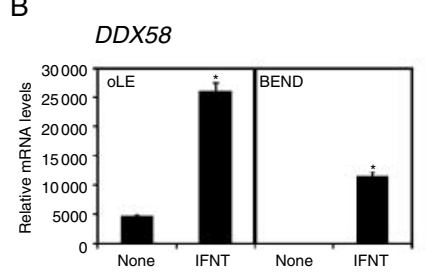

C PLSCR1

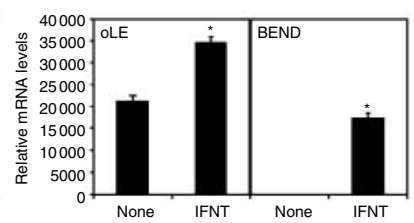

Figure 7 Semiquantitative RT-PCR analyses of DDX58 and PLSCR1 mRNAs in total cellular RNA isolated from immortalized ovine endometrial LE (oLE) and bovine endometrial (BEND) cells. Cells were treated with rolFNT $\left(10^{4} \mathrm{AVU} / \mathrm{ml}\right)$ for 0 or $24 \mathrm{~h}$ in each of three independent experiments. (A) AII PCR products were separated in a $1.5 \%$ agarose gel and stained with ethidium bromide. Total cellular RNA from the endometria of a day-16 pregnant ewe and sterile water (no template) were taken as positive and negative controls respectively. (B and C) A graph illustrating the effect of IFNT on relative mRNA levels for DDX58 and PLSCR1 is presented below each gel. The asterisk (*) denotes a significant $(P<0.001)$ effect of IFNT treatment. 


\section{In situ hybridization analyses}

Cell-specific mRNA expression in sections $(5 \mu \mathrm{m})$ of the ovine uterus was determined by radioactive in situ hybridization analysis as described previously (Spencer et al. 1999b, Song et al. 2006a). Briefly, deparaffinized, rehydrated, and deproteinated uterine tissue sections were hybridized with radiolabeled antisense or sense cRNA probes generated from linearized DDX58 and PLSCR1 partial cDNAs using in vitro transcription with $\left[\alpha^{-}{ }^{35} \mathrm{~S}\right]-\mathrm{UTP}$. After hybridization, washing, and RNase A digestion, slides were dipped in NTB2 liquid photographic emulsion (Kodak) and exposed at $4{ }^{\circ} \mathrm{C}$ for 1-2 weeks. Slides were developed in Kodak D-19 developer, counterstained with Gill's hematoxylin (Fisher Scientific, Fairlawn, NJ, USA), and then dehydrated through a graded series of alcohol to xylene. Coverslips were then affixed with Permount (Fisher). Images of representative fields were recorded under brightfield or darkfield illumination using a Nikon Eclipse 1000 photomicroscope (Nikon Instruments, Inc., Lewisville, TX, USA) fitted with a Nikon DXM1200 digital camera.

\section{Western blot analyses}

Monolayer cultures of the 2fTGH (parental) and U3A (STAT1deficient $2 \mathrm{fTGH}$ ) cell lines were grown in culture medium to $80 \%$ confluence in $100 \mathrm{~mm}$ diameter dishes. Cells were then left untreated as a control or were treated with rolFNT $\left(10^{4} \mathrm{AVU} / \mathrm{ml}\right)$ for $0,6,12$, or $24 \mathrm{~h}$ in each of three independent experiments. Protein concentrations were determined using the Bradford protein assay (Bio-Rad) with BSA as the standard. Whole cell extracts $(20 \mu \mathrm{g} /$ sample $)$ were separated by $15 \%$ SDS-PAGE, transferred to nitrocellulose, and probed with rabbit anti-human DDX58 antibody (Abcam Inc., Cambridge, MA, USA) and rabbit anti-human PLSCR1 antibody (kindly provided by Dr Peter J Sims; Dong et al. 2004) or normal nonimmune rabbit IgG (Sigma) according to the manufacturer's recommendations. Western blot analyses were conducted as described previously (Stewart et al. 2001a) using ECL (SuperSignal West Pico, Pierce, Rockford, IL, USA) and X-OMAT AR $X$-ray film (Kodak) according to the manufacturer's recommendations.

\section{Statistical analysis}

All quantitative data were subjected to least squares regression analyses (ANOVA) using the general linear model procedures of the Statistical Analysis System (SAS Institute, Cary, NC, USA). Slot blot hybridization data were corrected for differences in sample loading using the 18S rRNA data as a covariate. Data from studies one and two were analyzed for the effects of day, pregnancy status (cyclic or pregnant), treatment, and their interactions. All tests of significance were performed using the appropriate error terms according to the expectation of the mean squares for error. A $P$ value of 0.10 was taken to indicate a trend and a $P$ value of 0.05 or less was considered significant. Data are presented as least square means with S.E.M.S.

\section{Declaration of interest}

The authors declare that there is no conflict of interest that could be perceived as prejudicing the impartiality of the research reported.

\section{Funding}

This research was funded by the National Institutes of Health R01 Grant HD32534 (to F W Bazer and T E Spencer) and also supported by WCU (World Class University) program (R3110056) through the National Research Foundation of Korea funded by the Ministry of Education, Science, and Technology.

\section{Acknowledgements}

The authors thank Dr Peter J Sims (The Scripps Research Institute) for kindly providing the PLSCR1 antibody as well as Dr Thomas R Hansen (Colorado State University) for the BEND cells.

\section{References}

Alexenko AP, Leaman DW, Li J \& Roberts RM 1997 The antiproliferative and antiviral activities of IFN- $\tau$ variants in human cells. Journal of Interferon \& Cytokine Research 17 769-779. (doi:10.1089/jir.1997.17.769)

Ashworth CJ \& Bazer FW 1989 Changes in ovine conceptus and endometrial function following asynchronous embryo transfer or administration of progesterone. Biology of Reproduction 40 425-433. (doi:10.1095/biolreprod40.2.425)

Basse F, Stout JG, Sims PJ \& Wiedmer T 1996 Isolation of an erythrocyte membrane protein that mediates $\mathrm{Ca}^{2+}$-dependent transbilayer movement of phospholipid. Journal of Biological Chemistry 271 17205-17210. (doi:10.1074/jbc.271.29.17205)

Bazer FW 1992 Mediators of maternal recognition of pregnancy in mammals. Proceedings of the Society for Experimental Biology and Medicine 199 373-384.

Bazer FW \& Roberts RM 1983 Biochemical aspects of conceptusendometrial interactions. Journal of Experimental Zoology 228 373-383. (doi:10.1002/jez.1402280220)

Bazer FW, Spencer TE \& Ott TL 1998 Endocrinology of the transition from recurring estrous cycles to establishment of pregnancy in subprimate mammals. In The Endocrinology of Pregnancy, pp 1-34. Ed. FW Bazer. Totowa, NJ: Humana Press.

Bazer FW, Burghardt RC, Johnson GA, Spencer TE \& Wu G 2008 Interferons and progesterone for establishment and maintenance of pregnancy: interactions among novel cell signaling pathways. Reproductive Biology 8 179-211.

Bazer FW, Wu G, Spencer TE, Johnson GA, Burghardt RC \& Bayless K 2010 Novel pathways for implantation and establishment and maintenance of pregnancy in mammals. Molecular Human Reproduction 16 135-152. (doi:10.1093/molehr/gap095)

Breiman A, Grandvaux N, Lin R, Ottone C, Akira S, Yoneyama M, Fujita T, Hiscott J \& Meurs EF 2005 Inhibition of RIG-I-dependent signaling to the interferon pathway during hepatitis $C$ virus expression and restoration of signaling by IKKepsilon. Journal of Virology 79 3969-3978. (doi:10. 1128/JVI.79.7.3969-3978.2005)

Choi Y, Johnson GA, Burghardt RC, Berghman LR, Joyce MM, Taylor KM, Stewart MD, Bazer FW \& Spencer TE 2001 Interferon regulatory factortwo restricts expression of interferon-stimulated genes to the endometrial stroma and glandular epithelium of the ovine uterus. Biology of Reproduction 65 1038-1049. (doi:10.1095/biolreprod65.4.1038)

Choi Y, Johnson GA, Spencer TE \& Bazer FW 2003 Pregnancy and interferon $\tau$ regulate major histocompatibility complex class I and $\beta 2$ microglobulin expression in the ovine uterus. Biology of Reproduction 68 1703-1710. (doi:10.1095/biolreprod.102.012708) 
Cui XF, Imaizumi T, Yoshida H, Borden EC \& Satoh K 2004 Retinoic acidinducible gene-I is induced by interferon $-\gamma$ and regulates the expression of interferon- $\gamma$ stimulated gene 15 in MCF-7 cells. Biochemistry and Cell Biology 82 401-405. (doi:10.1139/o04-041)

Decker T, Lew DJ, Mirkovitch J \& Darnell JE Jr 1991 Cytoplasmic activation of GAF, an IFN- $\gamma$-regulated DNA-binding factor. EMBO Journal 10 927-932.

Der SD, Zhou A, Williams BR \& Silverman RH 1998 Identification of genes differentially regulated by interferon $\alpha, \beta$, or $\gamma$ using oligonucleotide arrays. PNAS 95 15623-15628. (doi:10.1073/pnas.95.26.15623)

Dioum EM, Chen R, Alexander MS, Zhang Q, Hogg RT, Gerard RD \& Garcia JA 2009 Regulation of hypoxia-inducible factor $2 \alpha$ signaling by the stress-responsive deacetylase sirtuin 1. Science 324 1289-1293. (doi:10.1126/science.1169956)

Dong B, Zhou Q, Zhao J, Zhou A, Harty RN, Bose S, Banerjee A, Slee R, Guenther J, Williams BR et al. 2004 Phospholipid scramblase 1 potentiates the antiviral activity of interferon. Journal of Virology $\mathbf{7 8}$ 8983-8993. (doi:10.1128/JVI.78.17.8983-8993.2004)

Farin CE, Imakawa K \& Roberts RM 1989 In situ localization of mRNA for the interferon, ovine trophoblast protein-1, during early embryonic development of the sheep. Molecular Endocrinology 3 1099-1107. (doi:10.1210/mend-3-7-1099)

Fleming JA, Choi Y, Johnson GA, Spencer TE \& Bazer FW 2001 Cloning of the ovine estrogen receptor- $\alpha$ promoter and functional regulation by ovine interferon- $\tau$. Endocrinology 142 2879-2887. (doi:10.1210/en. 142.7.2879)

Foy E, Li K, Sumpter R Jr, Loo YM, Johnson CL, Wang C, Fish PM, Yoneyama M, Fujita T, Lemon SM et al. 2005 Control of antiviral defenses through hepatitis $C$ virus disruption of retinoic acid-inducible gene-I signaling. PNAS 102 2986-2991. (doi:10.1073/pnas. 0408707102)

Fujita T, Sakakibara J, Sudo Y, Miyamoto M, Kimura Y \& Taniguchi T 1988 Evidence for a nuclear factor(s), IRF-1, mediating induction and silencing properties to human IFN- $\beta$ gene regulatory elements. EMBO Journal 7 3397-3405.

Gray CA, Adelson DL, Bazer FW, Burghardt RC, Meeusen EN \& Spencer TE 2004 Discovery and characterization of an epithelial-specific galectin in the endometrium that forms crystals in the trophectoderm. PNAS 101 7982-7987. (doi:10.1073/pnas.0402669101)

Han CS, Mathialagan N, Klemann SW \& Roberts RM 1997 Molecular cloning of ovine and bovine type I interferon receptor subunits from uteri, and endometrial expression of messenger ribonucleic acid for ovine receptors during the estrous cycle and pregnancy. Endocrinology 138 4757-4767. (doi:10.1210/en.138.11.4757)

Hansen TR, Austin KJ, Perry DJ, Pru JK, Teixeira MG \& Johnson GA 1999 Mechanism of action of interferon- $\tau$ in the uterus during early pregnancy. Journal of Reproduction and Fertility. Supplement 54 329-339.

Harada H, Fujita T, Miyamoto M, Kimura Y, Maruyama M, Furia A, Miyata T \& Taniguchi T 1989 Structurally similar but functionally distinct factors, IRF-1 and IRF-2, bind to the same regulatory elements of IFN and IFNinducible genes. Cell 58 729-739. (doi:10.1016/0092-8674(89)90107-4)

Harada H, Willison K, Sakakibara J, Miyamoto M, Fujita T \& Taniguchi T 1990 Absence of the type I IFN system in EC cells: transcriptional activator (IRF-1) and repressor (IRF-2) genes are developmentally regulated. Cell 63 303-312. (doi:10.1016/0092-8674(90)90163-9)

Harada H, Takahashi E, Itoh S, Harada K, Hori TA \& Taniguchi T 1994 Structure and regulation of the human interferon regulatory factor 1 (IRF-1) and IRF-2 genes: implications for a gene network in the interferon system. Molecular and Cellular Biology 14 1500-1509.

Van Heeke G, Ott TL, Strauss A, Ammaturo D \& Bazer FW 1996 High yield expression and secretion of the ovine pregnancy recognition hormone interferon- $\tau$ by Pichia pastoris. Journal of Interferon \& Cytokine Research 16 119-126. (doi:10.1089/jir.1996.16.119)

Imaizumi T, Aratani S, Nakajima T, Carlson M, Matsumiya T, Tanji K, Ookawa K, Yoshida H, Tsuchida S, McIntyre TM et al. 2002 Retinoic acid-inducible gene-I is induced in endothelial cells by LPS and regulates expression of COX-2. Biochemical and Biophysical Research Communications 292 274-279. (doi:10.1006/bbrc.2002.6650)

Imaizumi T, Hatakeyama M, Yamashita K, Yoshida H, Ishikawa A, Taima K, Satoh K, Mori F \& Wakabayashi K 2004a Interferon- $\gamma$ induces retinoic acid-inducible gene-I in endothelial cells. Endothelium 11 169-173. (doi:10.1080/10623320490512156)
Imaizumi T, Yagihashi N, Hatakeyama M, Yamashita K, Ishikawa A, Taima K, Yoshida H, Inoue I, Fujita T, Yagihashi S et al. 2004b Expression of retinoic acid-inducible gene-I in vascular smooth muscle cells stimulated with interferon- $\gamma$. Life Sciences 75 1171-1180. (doi:10. 1016/j.Ifs.2004.01.030)

Johnson GA, Burghardt RC, Newton GR, Bazer FW \& Spencer TE 1999a Development and characterization of immortalized ovine endometrial cell lines. Biology of Reproduction 61 1324-1330. (doi:10.1095/ biolreprod61.5.1324)

Johnson GA, Spencer TE, Hansen TR, Austin KJ, Burghardt RC \& Bazer FW $1999 b$ Expression of the interferon $\tau$ inducible ubiquitin cross-reactive protein in the ovine uterus. Biology of Reproduction 61 312-318. (doi:10.1095/biolreprod61.1.312)

Johnson JA, Hochkeppel HK \& Gangemi JD 1999c IFN- $\tau$ exhibits potent suppression of human papillomavirus E6/E7 oncoprotein expression. Journal of Interferon \& Cytokine Research 19 1107-1116. (doi:10.1089/ 107999099313046)

Johnson GA, Austin KJ, Collins AM, Murdoch WJ \& Hansen TR 1999d Endometrial ISG17 mRNA and a related mRNA are induced by interferon- $\tau$ and localized to glandular epithelial and stromal cells from pregnant cows. Endocrine 10 243-252. (doi:10.1007/BF02738623)

Johnson GA, Spencer TE, Burghardt RC, Joyce MM \& Bazer FW 2000 Interferon- $\tau$ and progesterone regulate ubiquitin cross-reactive protein expression in the ovine uterus. Biology of Reproduction 62 622-627. (doi:10.1095/biolreprod62.3.622)

Johnson GA, Stewart MD, Gray CA, Choi Y, Burghardt RC, Yu-Lee LY, Bazer FW \& Spencer TE 2001 Effects of the estrous cycle, pregnancy, and interferon $\tau$ on $2^{\prime}, 5^{\prime}$-oligoadenylate synthetase expression in the ovine uterus. Biology of Reproduction 64 1392-1399. (doi:10.1095/biolreprod64.5.1392)

Johnson GA, Joyce MM, Yankey SJ, Hansen TR \& Ott TL 2002 The interferon stimulated genes (ISG) 17 and Mx have different temporal and spatial expression in the ovine uterus suggesting more complex regulation of the Mx gene. Journal of Endocrinology 174 R7-R11. (doi:10.1677/joe.0.174R007)

Karin M 1991 Signal transduction and gene control. Current Opinion in Cell Biology 3 467-473. (doi:10.1016/0955-0674(91)90075-A)

Khan OA, Jiang H, Subramaniam PS, Johnson HM \& Dhib-Jalbut SS 1998 Immunomodulating functions of recombinant ovine interferon $\tau$ : potential for therapy in multiple sclerosis and autoimmune disorders. Multiple Sclerosis 4 63-69. (doi:10.1177/135245859800400204)

Kim S, Choi Y, Bazer FW \& Spencer TE 2003 Identification of genes in the ovine endometrium regulated by interferon $\tau$ independent of signal transducer and activator of transcription 1. Endocrinology 144 5203-5214. (doi:10.1210/en.2003-0665)

Levy DE, Kessler DS, Pine R, Reich N \& Darnell JE Jr 1988 Interferoninduced nuclear factors that bind a shared promoter element correlate with positive and negative transcriptional control. Genes and Development 2 383-393. (doi:10.1101/gad.2.4.383)

Li K, Foy E, Ferreon JC, Nakamura M, Ferreon AC, Ikeda M, Ray SC, Gale M Jr \& Lemon SM 2005 Immune evasion by hepatitis C virus NS3/4A protease-mediated cleavage of the Toll-like receptor 3 adaptor protein TRIF. PNAS 102 2992-2997. (doi:10.1073/pnas.0408824102)

Mamane Y, Heylbroeck C, Genin P, Algarte M, Servant MJ, LePage C, DeLuca C, Kwon H, Lin R \& Hiscott J 1999 Interferon regulatory factors: the next generation. Gene 237 1-14. (doi:10.1016/S03781119(99)00262-0)

Mirando MA, Short EC Jr, Geisert RD, Vallet JL \& Bazer FW 1991 Stimulation of $2^{\prime}, 5^{\prime}$-oligoadenylate synthetase activity in sheep endometrium during pregnancy, by intrauterine infusion of ovine trophoblast protein-1, and by intramuscular administration of recombinant bovine interferon- $\alpha$ 11. Journal of Reproduction and Fertility 93 599-607. (doi:10.1530/jrf.0.0930599)

Nguyen H, Hiscott J \& Pitha PM 1997 The growing family of interferon regulatory factors. Cytokine and Growth Factor Reviews 8 293-312. (doi:10.1016/S1359-6101(97)00019-1)

Ott TL, Yin J, Wiley AA, Kim HT, Gerami-Naini B, Spencer TE, Bartol FF, Burghardt RC \& Bazer FW 1998 Effects of the estrous cycle and early pregnancy on uterine expression of $\mathrm{Mx}$ protein in sheep (Ovis aries). Biology of Reproduction 59 784-794. (doi:10.1095/biolreprod59.4.784) 
Pellegrini S, John J, Shearer M, Kerr IM \& Stark GR 1989 Use of a selectable marker regulated by $\alpha$ interferon to obtain mutations in the signaling pathway. Molecular and Cellular Biology 9 4605-4612.

Phillippe M, Bradley DF, Ji H, Oppenheimer KH \& Chien EK 2006 Phospholipid scramblase isoform expression in pregnant rat uterus. Journal of the Society for Gynecologic Investigation 13 497-501. (doi:10. 1016/j.jsgi.2006.06.002)

Pine R, Canova A \& Schindler C 1994 Tyrosine phosphorylated p91 binds to a single element in the ISGF2/IRF-1 promoter to mediate induction by IFN $\alpha$ and IFN $\gamma$, and is likely to autoregulate the p91 gene. EMBO Journal 13 158-167.

Pontzer CH, Bazer FW \& Johnson HM 1991 Antiproliferative activity of a pregnancy recognition hormone, ovine trophoblast protein-1. Cancer Research 51 5304-5307.

Reich N, Evans B, Levy D, Fahey D, Knight E Jr \& Darnell JE Jr 1987 Interferon-induced transcription of a gene encoding a 15-kDa protein depends on an upstream enhancer element. PNAS 84 6394-6398. (doi:10.1073/pnas.84.18.6394)

Roberts RM, Ealy AD, Alexenko AP, Han CS \& Ezashi T 1999 Trophoblast interferons. Placenta 20 259-264. (doi:10.1053/plac.1998.0381)

Sakaki H, Imaizumi T, Matsumiya T, Kusumi A, Nakagawa H, Kubota K, Nishi N, Nakamura T, Hirashima M, Satoh K et al. 2005 Retinoic acidinducible gene-I is induced by interleukin-1 $\beta$ in cultured human gingival fibroblasts. Oral Microbiology and Immunology 20 47-50. (doi:10.1111/ j.1399-302X.2005.00181.x)

Schindler C, Shuai K, Prezioso VR \& Darnell JE Jr 1992 Interferondependent tyrosine phosphorylation of a latent cytoplasmic transcription factor. Science 257 809-813. (doi:10.1126/science.1496401)

Senger K, Merika M, Agalioti T, Yie J, Escalante CR, Chen G, Aggarwal AK \& Thanos D 2000 Gene repression by coactivator repulsion. Molecular Cell 6 931-937. (doi:10.1016/S1097-2765(05)00081-X)

Shuai K, Schindler C, Prezioso VR \& Darnell JE Jr 1992 Activation of transcription by IFN- $\gamma$ : tyrosine phosphorylation of a $91-k D$ DNA binding protein. Science 258 1808-1812. (doi:10.1126/science.1281555)

Song G, Spencer TE \& Bazer FW 2005 Cathepsins in the ovine uterus: regulation by pregnancy, progesterone, and interferon $\tau$. Endocrinology 146 4825-4833. (doi:10.1210/en.2005-0768)

Song G, Bazer FW, Wagner GF \& Spencer TE 2006a Stanniocalcin (STC) in the endometrial glands of the ovine uterus: regulation by progesterone and placental hormones. Biology of Reproduction 74 913-922. (doi:10. 1095/biolreprod.106.050807)

Song G, Spencer TE \& Bazer FW 2006b Progesterone and interferon- $\tau$ regulate cystatin $\mathrm{C}$ in the endometrium. Endocrinology 147 3478-3483. (doi:10.1210/en.2006-0122)

Song G, Bazer FW \& Spencer TE 2007 Pregnancy and interferon $\tau$ regulate RSAD2 and IFIH1 expression in the ovine uterus. Reproduction 133 285-295. (doi:10.1530/REP-06-0092)

Spencer TE \& Bazer FW 1996 Ovine interferon $\tau$ suppresses transcription of the estrogen receptor and oxytocin receptor genes in the ovine endometrium. Endocrinology 137 1144-1147. (doi:10.1210/en.137.3.1144)

Spencer TE, Ott TL \& Bazer FW $1996 \tau$-Interferon: pregnancy recognition signal in ruminants. Proceedings of the Society for Experimental Biology and Medicine 213 215-229.

Spencer TE, Ott TL \& Bazer FW 1998 Expression of interferon regulatory factors one and two in the ovine endometrium: effects of pregnancy and ovine interferon $\tau$. Biology of Reproduction 58 1154-1162. (doi:10. 1095/biolreprod58.5.1154)

Spencer TE, Bartol FF, Bazer FW, Johnson GA \& Joyce MM 1999a Identification and characterization of glycosylation-dependent cell adhesion molecule 1-like protein expression in the ovine uterus. Biology of Reproduction 60 241-250. (doi:10.1095/biolreprod60.2.241)

Spencer TE, Stagg AG, Ott TL, Johnson GA, Ramsey WS \& Bazer FW $1999 \mathrm{~b}$ Differential effects of intrauterine and subcutaneous administration of recombinant ovine interferon $\tau$ on the endometrium of cyclic ewes. Biology of Reproduction 61 464-470. (doi:10.1095/biolreprod 61.2.464)

Spencer TE, Burghardt RC, Johnson GA \& Bazer FW 2004 Conceptus signals for establishment and maintenance of pregnancy. Animal Reproduction Science 82-83 537-550. (doi:10.1016/j.anireprosci. 2004.04.014)

Stark GR \& Kerr IM 1992 Interferon-dependent signaling pathways: DNA elements, transcription factors, mutations, and effects of viral proteins. Journal of Interferon Research 12 147-151. (doi:10.1089/jir. 1992.12.147)

Stewart DM, Johnson GA, Vyhlidal CA, Burghardt RC, Safe SH, Yu-Lee LY, Bazer FW \& Spencer TE 2001 a Interferon- $\tau$ activates multiple signal transducer and activator of transcription proteins and has complex effects on interferon-responsive gene transcription in ovine endometrial epithelial cells. Endocrinology 142 98-107. (doi:10.1210/en.142.1.98)

Stewart MD, Johnson GA, Bazer FW \& Spencer TE $2001 b$ Interferon- $\tau$ $(I F N \tau)$ regulation of IFN-stimulated gene expression in cell lines lacking specific IFN-signaling components. Endocrinology 142 1786-1794. (doi:10.1210/en.142.5.1786)

Stewart MD, Choi Y, Johnson GA, Yu-Lee LY, Bazer FW \& Spencer TE 2002 Roles of Stat1, Stat2, and interferon regulatory factor-9 (IRF-9) in interferon $\tau$ regulation of IRF-1. Biology of Reproduction 66 393-400. (doi:10.1095/biolreprod66.2.393)

Sumpter R Jr, Loo YM, Foy E, Li K, Yoneyama M, Fujita T, Lemon SM \& Gale M Jr 2005 Regulating intracellular antiviral defense and permissiveness to hepatitis $C$ virus RNA replication through a cellular RNA helicase, RIG-I. Journal of Virology 79 2689-2699. (doi:10.1128/ JVI.79.5.2689-2699.2005)

Sun YW 1997 RIG-I, a human homolog gene of RNA helicase, is induced by retinoic acid during the differentiation of acute promyelocytic leukemia cell. Thesis. Shanhai Second Medical University.

Vallet JL, Gross TS, Fliss MF \& Bazer FW 1989 Effects of pregnancy, oxytocin, ovine trophoblast protein-1 and their interactions on endometrial production of prostaglandin $\mathrm{F}_{2 \alpha}$ in vitro in perifusion chambers. Prostaglandins 38 113-124. (doi:10.1016/0090-6980(89)90020-8)

Vallet JL, Barker PJ, Lamming GE, Skinner N \& Huskisson NS 1991 A low molecular weight endometrial secretory protein which is increased by ovine trophoblast protein- 1 is a $\beta 2$-microglobulin-like protein. Journal of Endocrinology 130 R1-R4. (doi:10.1677/joe.0.130R001)

Wu WX, Zhang Q, Unno N, Derks JB \& Nathanielsz PW 2000 Characterization of decorin mRNA in pregnant intrauterine tissues of the ewe and regulation by steroids. American Journal of Physiology. Cell Physiology 278 C199-C206.

Yoneyama $M$, Kikuchi $M$, Natsukawa T, Shinobu $N$, Imaizumi T, Miyagishi M, Taira K, Akira S \& Fujita T 2004 The RNA helicase RIG-I has an essential function in double-stranded RNA-induced innate antiviral responses. Nature Immunology 5 730-737. (doi:10.1038/ni1087)

Yuzawa E, Imaizumi T, Matsumiya T, Yoshida $\mathbf{H}$, Fukuhara $\mathbf{R}$, Kimura $\mathbf{H}$, Fukui A, Tanji K, Mori F, Wakabayashi K et al. 2008 Retinoic acidinducible gene-I is induced by interferon- $\gamma$ and regulates CXCL11 expression in HeLa cells. Life Sciences 82 670-675. (doi:10.1016/j.Ifs. 2007.12.025)

Zhou Q, Zhao J, Stout JG, Luhm RA, Wiedmer T \& Sims PJ 1997 Molecular cloning of human plasma membrane phospholipid scramblase. A protein mediating transbilayer movement of plasma membrane phospholipids. Journal of Biological Chemistry 272 18240-18244. (doi:10.1074/jbc. 272.29.18240)

Received 11 August 2010

First decision 22 September 2010

Accepted 6 October 2010 